\title{
Rare genetic variation implicated in non-Hispanic white families with Alzheimer disease
}

Gary W. Beecham, PhD, Badri Vardarajan, PhD, Elizabeth Blue, PhD, William Bush, PhD, James Jaworski, MPH, Sandra Barral, PhD, Anita DeStefano, PhD, Kara Hamilton-Nelson, MPH, Brian Kunkle, PhD,

Eden R. Martin, PhD, Adam Naj, PhD, Farid Rajabli, PhD, Christiane Reitz, MD, PhD, Timothy Thornton, PhD, Cornelia van Duijn, PhD, Allison Goate, PhD, Sudha Seshadri, MD, Lindsay A. Farrer, PhD, Eric Boerwinkle, PhD, Gerard Schellenberg, PhD, Jonathan L. Haines, PhD, Ellen Wijsman, PhD, Richard Mayeux, MD, and Margaret A. Pericak-Vance, PhD, for The Alzheimer's Disease Sequencing Project

Neurol Genet 2018;4:e286. doi:10.1212/NXG.0000000000000286

\section{Abstract}

\section{Objective}

To identify genetic variation influencing late-onset Alzheimer disease (LOAD), we used a large data set of non-Hispanic white (NHW) extended families multiply-affected by LOAD by performing whole genome sequencing (WGS).

\section{Methods}

As part of the Alzheimer Disease Sequencing Project, WGS data were generated for 197 NHW participants from 42 families (affected individuals and unaffected, elderly relatives). A twopronged approach was taken. First, variants were prioritized using heterogeneity logarithm of the odds (HLOD) and family-specific LOD scores as well as annotations based on function, frequency, and segregation with disease. Second, known Alzheimer disease (AD) candidate genes were assessed for rare variation using a family-based association test.

\section{Results}

We identified 41 rare, predicted-damaging variants that segregated with disease in the families that contributed to the HLOD or family-specific LOD regions. These included a variant in nitric oxide synthase 1 adaptor protein that segregates with disease in a family with 7 individuals with $\mathrm{AD}$, as well as variants in RP11-433J8, ABCA1, and FISP2. Rare-variant association identified 2 LOAD candidate genes associated with disease in these families: FERMT2 ( $p$-values $=0.001)$ and SLC24A4 ( $p$-value $=0.009)$. These genes still showed association while controlling for common index variants, indicating the rare-variant signal is distinct from common variation that initially identified the genes as candidates.

\section{Conclusions}

We identified multiple genes with putative damaging rare variants that segregate with disease in multiplex $\mathrm{AD}$ families and showed that rare variation may influence $\mathrm{AD}$ risk at $\mathrm{AD}$ candidate genes. These results identify novel $\mathrm{AD}$ candidate genes and show a role for rare variation in LOAD etiology, even at genes previously identified by common variation.

\author{
Correspondence \\ Dr. Beecham \\ gbeecham@med.miami.edu
}

From the John P. Hussman Institute for Human Genomics (G.W.B., J.J., K.H.-N., B.K., E.R.M., F.R., M.A.P.-V.), University of Miami, Miller School of Medicine; Dr. John T. Macdonald Foundation
Department of Human Genetics (G.W.B., E.R.M., M.A.P.-V.), University of Miami, Miller School of Medicine, FL; The Taub Institute for Research on Alzheimer's Disease and the Aging Brain
(B.V., S.B., C.R., R.M.), Columbia University; The Gertrude H. Segievsky Center (B.V., S.B., C.R., R.M.), Columbia University, New York Presbyterian Hospital; Division of Medical Genetics (E. Blue,
E.W.), Department of Medicine, University of Washington, Seattle; Institute for Computational Biology (W.B., J.L.H.), Case Western Reserve University, Cleveland, OH; Department of Neurology
(A.D., S.S., L.A.F.), Boston University School of Medicine; Department of Biostatistics (A.D., S.S., L.A.F.), Boston University School of Medicine, MA; School of Medicine (A.N., G.S.), University of
Pennsylvania, Philadelphia; Department of Biostatistics (T.T., E.W.), University ofWashington, Seattle; Erasmus Medical University (C.D.), Rotterdam, The Netherlands; Icahn School of Medicine
at Mount Sinai (A.G.), New York, NY; Department of Medicine (L.A.F.), Boston University School of Medicine, MA; and University of Texas (E. Boerwinkle), Houston.
Funding information and disclosures are provided at the end of the article. Full disclosure form information provided by the authors is available with the full text of this article at Neurology.org/NG.

Co-contributors are listed at links.Iww.com/NXG/A132.

The Article Processing Charge was funded by the authors.

This is an open access article distributed under the terms of the Creative Commons Attribution-NonCommercial-NoDerivatives License 4.0 (CC BY-NC-ND), which permits downloading and sharing the work provided it is properly cited. The work cannot be changed in any way or used commercially without permission from the journal. 


\section{Glossary}

ADSP = Alzheimer Disease Sequencing Project; $\mathbf{C H}=$ Caribbean Hispanic; HLOD $=$ heterogeneity logarithm of the odds; LOAD = late-onset Alzheimer disease LOD = logarithm of the odds; LRP1 = LDL-receptor-related protein 1; MAF = Minor allele frequency; NHGRI = National Human Genome Research Institute; NHW = non-Hispanic white; NOS1AP = nitric oxide synthase 1 adaptor protein; $\mathbf{Q C}=$ quality control; SNP = single nucleotide polymorphism; $\mathbf{W E S}=$ whole exome sequencing; WGS $=$ whole genome sequencing.

Late-onset Alzheimer disease (LOAD) is a neurodegenerative disease, characterized by progressive dementia, and pathologic changes include neuronal loss, neurofibrillary tangles, and amyloid-beta deposits. ${ }^{1}$ LOAD is highly heritable $(60 \%-80 \%)$, but most of this heritability remains unexplained, despite the identification of genetic factors that influence LOAD. ${ }^{2}$ These factors include the $A P O E$ gene, as well as other genes identified through genome-wide association studies (GWAS) and a limited number of studies of rare genetic variation. ${ }^{3-9}$ While these factors have replicable association with LOAD, few of the underlying causal variants have been definitively identified.

To identify additional genes influencing LOAD and to better understand known LOAD genes, the Alzheimer Disease Sequencing Project (ADSP) was established..$^{10}$ A key component of the ADSP is inclusion of whole genome sequencing (WGS) in large, multiply-affected LOAD families of non-Hispanic white (NHW) and Caribbean Hispanic $(\mathrm{CH})$ ancestry. This familybased design enriches the study for risk variation, making it ideal to identify novel risk variants. ${ }^{11}$ Family structure facilitates the prioritization of risk variation through linkage and segregationbased approaches. In this study, we report on analyses of the NHW families. Two primary approaches were taken: examination of linkage regions segregating with disease in these families to identify novel genes and a gene-based association analysis to rare variation at known Alzheimer disease $(\mathrm{AD})$ candidate genes. Results indicate that rare variants play a role in LOAD multiplex families, both at novel genes identified through linkage and through rare variation at $\mathrm{AD}$ candidate genes.

\section{Methods}

\section{The Alzheimer Disease Sequencing Project}

Families were assembled as part of the ADSP. The ADSP is a collaboration of the LOAD genetics research community, the National Institutes on Aging, and the National Human Genome Research Institute (NHGRI). The full design is described elsewhere. ${ }^{11}$ The ADSP includes contributors from the Alzheimer Disease Genetics Consortium, the neurology working group of the Cohorts for Heart and Aging Research in Genomic Epidemiology (CHARGE), as well as 3 NHGRI sequencing centers at Baylor University, the Broad Institute, and Washington University. Data are available through dbGaP (phs000572).

\section{Family selection and design}

Approximately 1,400 multiplex LOAD families were reviewed for inclusion. Families were derived from the National
Institute on Aging Late Onset of Alzheimer's Disease family study, the National Cell Repository for Alzheimer's Disease, and families contributed by investigators from Columbia University, University of Miami, University of Washington, University of Pennsylvania, Case Western Reserve University, and Erasmus University. Families analyzed here were of NHW ( $\mathrm{CH}$ descent families analyzed elsewhere $)^{12}$ and were required to have multiple members with $\mathrm{LOAD}$, available genomic DNA, and available APOE genotypes. We excluded families known to carry mendelian $\mathrm{AD}$ mutations or were pathologically confirmed non-Alzheimer dementia.

Families meeting initial criteria were prioritized and chosen based on the number of affected individuals, number of generations affected, age at onset of clinical symptoms, and presence of APOE $\varepsilon 4$ risk alleles (table 1). Details of criteria and selection process are described elsewhere. ${ }^{10}$ No $\varepsilon 4 / \varepsilon 4$ individuals were included. Cognitively intact participants were selected if available and informative for phasing.

All cases met National Institute of Neurological DiseasesAlzheimer's NINCDS-ADRDA criteria for possible, probable or definite $\mathrm{AD} .{ }^{13}$ Unaffected individuals were free of clinical $\mathrm{AD}$ at the most recent cognitive assessment. In total, $42 \mathrm{NHW}$ families were included. These families included 208 affected individuals and 185 unaffected individuals with array data available, of which 164 affected individuals and 33 unaffected individuals were included in the sequencing experiment.

\section{Standard protocol approvals, registrations, and patient consents}

All individuals (or caregivers) provided written informed consent for genomic studies, including broad data sharing, and were assessed with the approval of the relevant institutional review boards.

\section{NGS sequencing}

WGS was performed at the NHGRI sequencing centers at the Broad Institute (Boston, MA), Baylor College of Medicine (Houston, TX), and Washington University (St. Louis, MS). Samples were sequenced using Illumina instruments to a minimum average $30 \times$ depth. Details of the sequencing experiments are described elsewhere. ${ }^{14}$

\section{NGS calling and quality control}

Raw NGS data were aligned to hg19 using BWA. ${ }^{15}$ Genotype calling was performed using Atlas (v2). ${ }^{16}$ Extensive variantlevel quality control (QC) was performed (appendix e-1, 
Table 1 Priority variants from consensus linkage regions

\begin{tabular}{|c|c|c|c|c|c|c|c|c|}
\hline Chrm & Position & RS ID & Family & Gene & Alleles & Consequence & CADD & MAF (1kGP) \\
\hline 1 & $162,167,769$ & & LD0254F & NOS1AP & $\mathrm{C} / \mathrm{T}$ & Intron variant & 1.2 & NA \\
\hline 1 & $162,207,390$ & & LD0254F & NOS1AP & $\mathrm{A} / \mathrm{T}$ & Intron variant & 0.2 & NA \\
\hline 1 & $162,223,640$ & & LD0254F & NOS1AP & $\mathrm{A} / \mathrm{G}$ & Intron variant & 13.6 & NA \\
\hline 1 & $162,479,200$ & & UM0464F & UHMK1 & $T / G$ & Intron variant & 0.4 & 0 \\
\hline 1 & $162,564,187$ & & LD1223F & UAP1 & $\mathrm{A} / \mathrm{G}$ & Intron variant & 8.7 & 0.008 \\
\hline 1 & $162,564,187$ & & LD1223F & UAP1 & $\mathrm{A} / \mathrm{G}$ & Intron variant & 8.7 & 0.008 \\
\hline 1 & $162,700,025$ & & UM0464F & DDR2 & $\mathrm{A} / \mathrm{C}$ & Intron variant & 0.5 & 0.009 \\
\hline 1 & $162,735,057$ & & UM0464F & DDR2 & $\mathrm{G} / \mathrm{A}$ & Intron variant & 0.7 & 0.009 \\
\hline 1 & $162,739,064$ & & UM0464F & DDR2 & $\mathrm{G} / \mathrm{A}$ & Intron variant & 5.4 & 0.009 \\
\hline 1 & $162,742,651$ & & LD0254F & DDR2 & $\mathrm{G} / \mathrm{A}$ & Intron variant & 0.1 & 0.001 \\
\hline 1 & $162,751,967$ & & LD0254F & DDR2 & T/A & 3' UTR variant & 6.6 & 0.009 \\
\hline 1 & $162,757,273$ & & LD1223F & DDR2 & $\mathrm{T} / \mathrm{C}$ & Upstream gene variant & 2.2 & 0.009 \\
\hline 1 & $162,928,238$ & & UM0464F & & $\mathrm{G} / \mathrm{A}$ & Intergenic variant & 0.9 & 0.002 \\
\hline 1 & $163,032,461$ & & LD0254F & & $\mathrm{T} / \mathrm{A}$ & Intergenic variant & 1.9 & 0.002 \\
\hline 1 & $163,202,875$ & & UM0464F & RGS5 & $\mathrm{G} / \mathrm{A}$ & Intron variant & 8.3 & 0.002 \\
\hline 1 & $163,578,427$ & & UM0464F & & $\mathrm{C} / \mathrm{A}$ & Intergenic variant & 4.7 & 0.003 \\
\hline 1 & $163,749,571$ & & LD0949F & & $A / G$ & Intergenic variant & 7.2 & 0.002 \\
\hline 1 & $163,841,625$ & & UM0464F & & $\mathrm{C} / \mathrm{T}$ & Intergenic variant & 7.1 & 0.010 \\
\hline 1 & $164,034,469$ & rs187504850 & UM0464F & & $A / G$ & Intergenic variant & 19.6 & NA \\
\hline 1 & $164,448,463$ & & UM0464F & & $\mathrm{G} / \mathrm{A}$ & Intergenic variant & 3.2 & 0.003 \\
\hline 1 & $164,622,647$ & & LD0949F & PBX1 & $\mathrm{G} / \mathrm{A}$ & Intron variant & 1.2 & 0.006 \\
\hline 1 & $164,887,661$ & & UM0464F & & $\mathrm{C} / \mathrm{T}$ & Downstream gene variant & 8.2 & 0.005 \\
\hline 1 & $165,253,949$ & & LD0254F & LMX1A & $\mathrm{C} / \mathrm{T}$ & Intron variant & 14.7 & 0.002 \\
\hline 1 & $165,342,593$ & & UM0464F & & $\mathrm{G} / \mathrm{A}$ & Intergenic variant & 5.9 & 0.010 \\
\hline 1 & $165,532,785$ & & LD1223F & LRRC52 & $\mathrm{G} / \mathrm{A}$ & Synonymous variant & 18.3 & 0.004 \\
\hline 14 & $95,913,507$ & rs191535004 & LD0949F & SYNE3 & $\mathrm{G} / \mathrm{A}$ & Intron variant & 0.7 & 0.008 \\
\hline 14 & $95,923,822$ & & UM0464F & SYNE3 & $\mathrm{C} / \mathrm{T}$ & Intron variant & 3.5 & 0.008 \\
\hline 14 & $96,449,175$ & & UM0464F & & $\mathrm{C} / \mathrm{A}$ & Intergenic variant & 0.8 & NA \\
\hline 14 & $96,568,984$ & & UM0464F & & $\mathrm{C} / \mathrm{A}$ & Regulatory region variant & 1.5 & NA \\
\hline 14 & $96,923,339$ & & LD0254F & AK7 & $\mathrm{C} / \mathrm{T}$ & Noncoding transcript exon variant & 0.1 & 0.008 \\
\hline 14 & $97,029,358$ & & UM0464F & PAPOLA & $C / G$ & Intron variant & 10.4 & NA \\
\hline 14 & $97,228,875$ & & LD0949F & RP11-433J8.2 & $\mathrm{A} / \mathrm{G}$ & Intron variant & 12.3 & 0.003 \\
\hline
\end{tabular}

Abbreviations: $\mathrm{CADD}=$ Combined Annotation Dependent Depletion score; Chrm = chromosome; MAF (1 kGP) = Minor Allele Frequency among the European samples in the 1,000 Genomes Project data; UTR = untranslated region.

links.lww.com/NXG/A117). Principal components analysis was used to assess population substructure, using the EIGENSTRAT. ${ }^{17}$ Array data were compared with WGS data to assess and confirm the pedigree structure for all individuals. Additional details of QC are reported elsewhere. ${ }^{14}$

\section{Linkage analyses}

MERLIN v1.1.2 software $^{18}$ was used to perform parametric and nonparametric multipoint linkage analyses on the array data available for the entire family. Nonparametric analyses are described in detail elsewhere. ${ }^{19}$ For parametric multipoint 
analyses, we first pruned markers to minimize linkage disequilibrium $\left(r^{2}<0.01\right)$ using PLINK v1.07 software. ${ }^{20}$ Using this pruned grid of markers, parametric multipoint linkage analyses were performed using a rare disease allele frequency (0.0001) and a dominant model with incomplete penetrance (noncarrier 0.01 and carrier 0.90). Consensus linkage regions (i.e., consistent across multiple families) were defined as peak HLOD $\geq 3.3$ per Lander and Kruglyak. ${ }^{21}$ Any family with peak family-specific LOD $>0.58$ in the consensus region was considered a contributor to the consensus signal. Familyspecific linkage regions were defined as regions with a parametric family-specific LOD $>2$.

\section{Annotations}

Variants were annotated for location, gene (if applicable), putative function (missense, nonsense, splice site, etc.), combined annotation dependent depletion (CADD) score (a quantitative summary of putative function and conservation), ${ }^{22}$ contextual analysis of transcription factor occupancy (CATO) $\operatorname{scores}^{23}$ for intergenic variation, and allele frequency in the NHW families and in the 1,000 Genomes Project European-ancestry populations. ${ }^{24}$ As a QC measure, we used BLAST to interrogate the genome for similar sequence as the high-priority variants, to ensure uniqueness of the relevant sequence. ${ }^{25}$

\section{Variant filtering and prioritization}

Variants were filtered based on complete segregation among affected individuals (and absent from unaffected individuals) and rarity (minor allele frequency $[\mathrm{MAF}]<0.05$ in our data set, $<0.01$ in 1,000 Genomes Project data). Additional prioritization was applied to variants with high CADD scores, were observed in multiple families, had CATO predictions, had multiple filtered variants in the same gene, or showed nominal association in the ADSP case-control analyses.

\section{Validation genotyping}

High-priority genotypes were validated using Sanger sequencing of whole genome sequenced family members to confirm carrier/ noncarrier status. Sequencing was performed using standard protocol on genomic DNA ( 50 ng). Details of validation typing are in appendix e-1 (links.lww.com/NXG/A117).

\section{Gene-based association tests}

Gene-based association tests were performed using the FSKAT v1 software. ${ }^{26}$ A cutoff of MAF $<0.02$ was used among the nonFinnish European ancestry populations in the 1,000 Genomes Project data $(1 \mathrm{kGP})^{24}$. Variants were analyzed in 2 sets: (1) damaging rare variants (loss-of-function variants, nonsense, stop-loss, etc and those predicted to be damaging) and (2) damaging variants plus all nonsynonymous variants. Genes with only a single variant were excluded. FSKAT was applied to the remaining genes using 2 models: one adjusted for age, sex, and the top 10 principal components and the other unadjusted.

\section{Candidate gene list}

Candidate genes (appendix e-1, links.lww.com/NXG/A117) were selected from replicable population and family $\mathrm{AD}$ genetics studies, mostly from GWAS of LOAD or known early-onset $\mathrm{AD}$ genes. $^{4-9}$

\section{Data availability}

Anonymized data are available by request from qualified investigators through dbGaP (phs000572.v1.p1) and through the National Institute on Aging Genetics of Alzheimer Disease Data Storage Site (www.niagads.org).

\section{Results}

\section{Consensus linkage regions}

Linkage scans identified 2 primary "consensus" linkage regions (peak HLOD $\geq 3.3)^{21}$ : a parametric multipoint peak on chromosome 1q23 (peak HLOD = 3.58; 162.2-165.8 Mb; figure 1A) and a nonparametric multipoint peak on chromosome $14 \mathrm{q} 32$ (LOD = 4.18; 98.9-99.6 Mb; figure $1 \mathrm{~B})$. The $1 \mathrm{q} 23$ region was supported (LOD > 0.58) by 8 families (LD0241F, LD0254F, LD0856F, LD1223F, LD1260F, UM0196F, UM0463F, and UM0464F), while the $14 \mathrm{q} 32$ region was supported by 4 families (LD0223F, LD0949F, LD1223F, and UP0004F). ${ }^{19}$

In total, there were 86 rare $(\mathrm{MAF}<0.011 \mathrm{kGP})$ variants that segregated with disease in sequenced affected individuals in at least 1 of the 8 families that supported the chromosome 1 peak. Of the 86 variants, 43 were genic (50\%) and 43 were intergenic (50\%). This initial set of 86 segregating variants was further refined by requiring variants to also be absent from unaffected individuals in the family (if available), have moderate-to-high

Figure Summary of consensus linkage regions on chromosomes 1 and 14
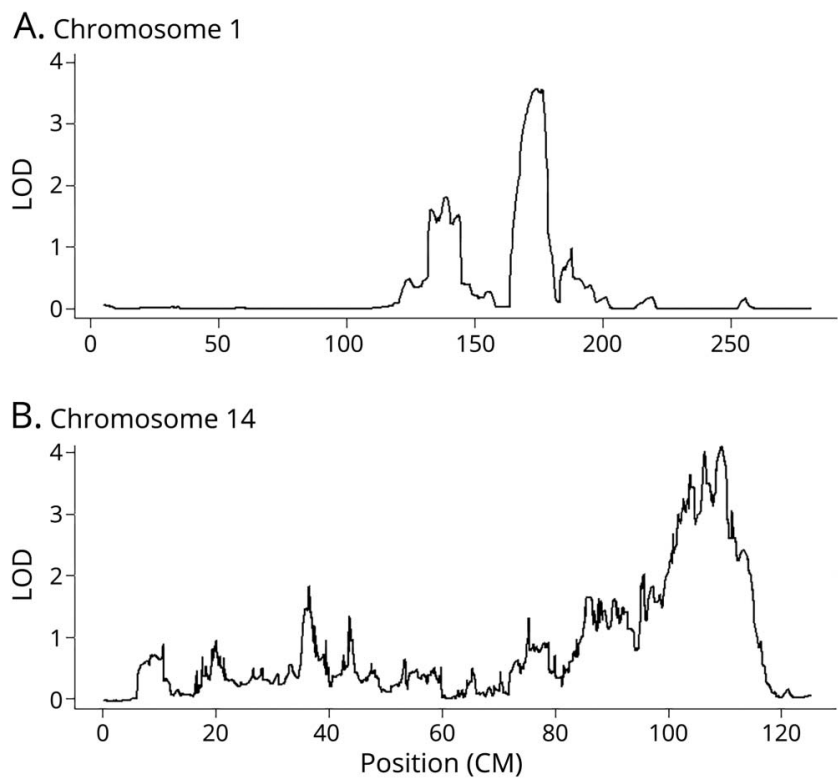

(A) Peak LOD region on chromosome 1. X-axis denotes positions in centimorgans. Y-axis denotes the LOD score at the corresponding position. (B) Peak LOD region on chromosome 14 . X-axis denotes positions in centimorgans. $Y$-axis denotes the LOD score at the corresponding position. 
CADD (CADD > 10), CATO predictions, or be seen in multiple families. Of the 86 variants, 24 matched these criteria and were considered "high priority." At the 14q32 locus, we identified 23 rare variants segregating with disease among affected individuals in at least 1 of the 4 families supported the linkage signal. Of this set, there were 7 variants absent from the unaffected individuals, had high CADD predictions, or were seen in multiple families. In total, 31 variants in the consensus linkage regions were prioritized; of these, 29 variants were validated using Sanger sequencing, 1 was a false positive, and 1 could not have a reliable assay developed.

A number of interesting results come out of this set of 29 confirmed variants (table 1). In the 1q23 region, a variant (chr1: $162,223,640 \mathrm{~A} / \mathrm{G}$ ) in nitric oxide synthase 1 adaptor protein (NOS1AP) segregates with disease in family UM0464F with 7 individuals with $\mathrm{AD}$ (family-specific $\mathrm{LOD}=2.62$; figure e-1, links. lww.com/NXG/A119); while the variant is intronic, it has a moderate CADD score (13.6) and is completely absent in the $1 \mathrm{kGP}$ reference data set. Other variants in NOS1AP (chr1: $162,167,769 \mathrm{C} / \mathrm{T}$; chr1:162,207,390 A/T) segregate with disease in family LD0254F (figure e-2, links.lww.com/NXG/A120). In the $14 \mathrm{q} 32$ region, an intronic variant in ncRNA RP11-433J8 segregates with disease in family LD1223F (6 AD family members; family-specific LOD $=1.45$ ); the variant was also present in a second family (LD0307F) although it was not present in all $\mathrm{AD}$ individuals. The variant is rare in $1 \mathrm{kGP}(\mathrm{MAF}=0.003)$ and has a moderate $\mathrm{CADD}$ score $(\mathrm{CADD}=12.2)$.

\section{Family-specific linkage regions}

In addition to the consensus linkage regions, there were 10 family-specific regions identified using parametric multipoint linkage (table 2). These regions showed family-specific LOD scores $>2$. Among the 10 regions, there were 647 variants that were rare $(\mathrm{MAF}<0.01 \mathrm{kGP})$ and segregated among the affected individuals in family with the LOD score $>2$. The 647 variants were further prioritized based on absence in unaffected family members with WGS, high CADD predictions, as well as presence in multiple families, identifying 13 additional variants as high priority (table 3 ). Twelve of these 13 variants were validated using an orthogonal technology (the last could not have a reliable assay developed).

Among the family-specific regions, a missense variant (rs137854495) in the chromosome 9 ABCA1 (ATP binding cassette subfamily A member 1) gene segregated with disease in a family with 4 individuals affected with $\mathrm{AD}$ (family-specific LOD $=2.04)$. The variant was absent in the $1 \mathrm{kGP}$ reference data set and had a high CADD score $(\mathrm{CADD}=34)$. Two missense variants in FSIP2 (fibrous sheath interacting protein 2) segregates with disease in a single family with $7 \mathrm{AD}$ family members (family-specific LOD $=2.07$ ). Both variants were rare in $1 \mathrm{kGP}(\mathrm{MAF}<0.001)$ and had high CADD scores $(\mathrm{CADD}=25.2$ and 22.6). This analysis also identified a missense variant with high CADD $(\mathrm{CADD}=32)$ in TTC3, from family UM0146F. This variant was previously identified through whole exome sequencing (WES) in the same family and is described elsewhere. ${ }^{27}$

\section{Candidate genes}

FSKAT, a family-based kernel test for association of sets of variants, was used to perform gene-based association in the families $^{27}$ (Table 4). A list of 31 candidate genes (identified from GWAS and studies of familial $\mathrm{AD}$ ) was tested for association with LOAD. Two genes showed association with LOAD in the unadjusted analysis that included nonsynonymous variants: FERMT2 ( $p$-value $=0.001)$ and SLC24A4 ( $p$-value $=0.009)$. The association in FERMT2 survives a Bonferroni correction for 31 genes tested $(p$-value $=0.05 / 31=0.0016)$. Both genes still showed association after adjusting for age, sex, and the top 10

Table 2 Family-specific linkage regions

\begin{tabular}{|c|c|c|c|c|c|c|}
\hline Family ID & Chrm & cM (start) & cM (end) & BP (start) & BP (end) & Peak LOD \\
\hline UM0458F & 12 & 0.18 & 41.96 & 0.38 & 20.56 & 2.95 \\
\hline UM0458F & 14 & 6.03 & 15.44 & 21.64 & 24.64 & 2.7 \\
\hline UM0146F & 21 & 41.07 & 49 & 36.55 & 40.37 & 2.63 \\
\hline UM0146F & 19 & 76.43 & 85.05 & 48.55 & 51.38 & 2.23 \\
\hline UP0005F & 1 & 131.84 & 144.67 & 103.72 & 115.74 & 2.07 \\
\hline UP0005F & 2 & 188.73 & 210.97 & 183.63 & 213.07 & 2.07 \\
\hline UP0005F & 16 & 78.58 & 91.44 & 58.51 & 73.81 & 2.07 \\
\hline UM0463F & 5 & 138.9 & 146.8 & 131.38 & 141.03 & 2.06 \\
\hline UP0001F & 9 & 106.1 & 116.2 & 104.11 & 112.23 & 2.04 \\
\hline UP0001F & 9 & 95.12 & 105.57 & 92.41 & 103.64 & 2.04 \\
\hline
\end{tabular}

Abbreviations: BP (start) and BP (end) = position of the region in megabases; Chrm = Chromosome; $\mathrm{CM}$ (start) and $\mathrm{cM}$ (end) = position of the region in centimorgans; LOD = logarithm of the odds. 
Table 3 Priority variants from family-specific linkage regions

\begin{tabular}{|c|c|c|c|c|c|c|c|}
\hline Chrm & Position & Gene & Alleles & Family & Consequence & CADD & MAF (1kGP) \\
\hline 2 & $186,611,520$ & FSIP2 & $\mathrm{C} / \mathrm{T}$ & UP0005F & Missense variant & 25.2 & 0.001 \\
\hline 2 & $186,611,521$ & FSIP2 & $\mathrm{G} / \mathrm{T}$ & UP0005F & Missense variant & 22.6 & 0.001 \\
\hline 2 & $199,347,563$ & PLCL1 & $A / G$ & UP0005F & Intron variant & 17.7 & 0.010 \\
\hline 2 & $208,614,446$ & CCNYL1 & C/G & UP0005F & Intron variant & 20.1 & 0.001 \\
\hline 9 & $100,819,143$ & NANS & $\mathrm{C} / \mathrm{T}$ & UP0001F & Missense variant & 22.5 & 0.001 \\
\hline 9 & $107,584,795$ & $\mathrm{ABCA} 1$ & $\mathrm{G} / \mathrm{A}$ & UP0001F & Missense variant & 34.0 & NA \\
\hline 12 & $16,342,622$ & SLC15A5 & $\mathrm{G} / \mathrm{A}$ & UM0458F & Missense variant & 24.0 & 0.008 \\
\hline 12 & $17,149,860$ & & $\mathrm{~T} / \mathrm{A}$ & UM0458F & Downstream gene variant & 16.4 & 0.010 \\
\hline 12 & $18,891,317$ & CAPZA3 & $\mathrm{C} / \mathrm{T}$ & UM0458F & Missense variant & 21.4 & 0.005 \\
\hline 16 & $61,999,830$ & $\mathrm{CDH} 8$ & $\mathrm{~A} / \mathrm{C}$ & UP0005F & Intron variant & 15.5 & 0.007 \\
\hline 16 & $70,546,287$ & COG4 & $\mathrm{C} / \mathrm{T}$ & UP0005F & Missense variant & 23.9 & NA \\
\hline 16 & $73,127,644$ & HCCAT5 & $A / G$ & UP0005F & Noncoding transcript exon variant & 16.3 & 0.002 \\
\hline 21 & $38,534,308$ & $\pi \mathrm{TC3}$ & C/G & UM0146F & Missense variant & 32.0 & NA \\
\hline
\end{tabular}

Abbreviations: $\mathrm{CADD}=$ Combined Annotation Dependent Depletion score; Chrm = chromosome; MAF $(1 \mathrm{kGP})=$ minor allele frequency among European samples in the 1,000 Genomes Project data.

principal components (FERMT2 $p$-value $=0.002 ; S L C 24 A 4$ $p$-value $=0.023)$. The PICALM gene also showed nominal association after adjusting for age, sex, and principal components $(p$-value $=0.032$; unadjusted $p$-value $=0.111)$. $S L C 24 A 4$ also showed nominal association in the damaging variant-only analysis ( $p$-value $=0.026$ ). Because these 3 genes were all initially identified using GWAS, we also performed the association analysis with the genotyped GWAS index single nucleotide polymorphisms (SNPs) as covariates in the FSKAT model (rs17125944 for FERMT2, rs10498633 for SLC24A4, and rs10792832 for PICALM). Each gene still showed evidence of association after including index SNP genotypes as covariates $(F E R M T 2 p$-value $=0.002, S L C 24 A 4 p$-value $=0.015$, PICALM $p$-value $=0.021)$.

Because the gene of interest for a particular associated locus may not be the gene physically closest to the index SNP, as a secondary analysis, we expanded the list of 31 candidate genes to include genes near the GWAS index SNPs $( \pm 1,000,000 \mathrm{bp})$. In this analysis, an additional 586 genes were tested using FSKAT. Near the FERMT2 locus (within $100 \mathrm{~kb}$ downstream), the genes STYX, PSMC6, and GNPNAT1 all showed association in the analysis including nonsynonymous variants ( $p$-values $=0.0011,0.0012$, and 0.0016 , respectively). STYX, in particular, also showed nominal association in a large case-control WES study conducted by the ADSP $(p$-value $=0.00119) .{ }^{28}$ As with FERMT2, the $p$-values did not appreciably change when adjusting for age, sex, and principal components ( $p$-values $=0.0013,0.0016$, and 0.0024 , respectively). Additional genes showed association in the nonsynonymous analysis include MGC45922 ( $p$-value = 0.0030; near CD33), TAP2 ( $p$-value $=0.0043$; near HLA-
DRB1/DRB5; $p$-value $=0.0047$ in the ADSP WES analysis), and FAM210B ( $p$-value $=0.0084$; near CASS4), when adjusting for age, sex, and principal components. In the analysis of damaging variants, the CPSF2 gene was associated in the adjusted analysis ( $p$-value $=0.000498)$, which would survive a Bonferroni multiple testing correction for 586 genes. This gene is located near the SLC24A4 gene and was also nominally associated in the ADSP WES analyses ( $p$-value = $0.034)$. The FIS1 gene also showed evidence of association in the unadjusted analysis ( $p$-value $=0.00748$, near ZCWPW1; unadjusted analysis $p$-value $=0.0147)$ and was also nominally associated in the ADSP WES analyses ( $p$-value $=0.034$ ).

\section{Discussion}

To identify rare variation influencing LOAD, we performed analyses of WGS data in NHW families multiply affected for LOAD. A two-pronged approach was taken: examination of linkage regions identified through analysis of genome-wide genotyping array data and a gene-based association analysis of rare coding variants, focusing on $\mathrm{AD}$ candidate loci identified in GWAS. These results indicate a potential role for rare variants in LOAD etiology. Numerous rare, predicted damaging rare variants were identified that segregate with disease in multiplex LOAD families and were validated with independent technologies. Additionally, rare variation in LOAD candidate genes was associated with $\mathrm{AD}$ in these multiplex families. This association persisted even when the common variant index SNPs were included in the models, indicating the rare variant association is likely distinct from the common variants that initially implicated the genes. 
Table 4 Gene-based association test results at known AD candidate genes

\begin{tabular}{|c|c|c|c|c|}
\hline \multirow[b]{2}{*}{ Gene } & \multicolumn{2}{|c|}{ Putative damaging + nonsynonomous } & \multicolumn{2}{|c|}{ Putative damaging } \\
\hline & $p$-Value (unadj) & $p$-Value (adj) & $p$-Value (unadj) & $p$-Value (adj) \\
\hline ABCA7 & 0.534 & 0.414 & 0.782 & 0.657 \\
\hline AKAP9 & 0.226 & 0.167 & 0.115 & 0.145 \\
\hline APOE & 0.334 & 0.228 & - & - \\
\hline APP & 0.802 & 0.651 & - & - \\
\hline BIN1 & 0.422 & 0.339 & - & - \\
\hline CASS4 & 0.159 & 0.164 & 0.527 & 0.732 \\
\hline CD2AP & 0.939 & 0.892 & 0.110 & 0.216 \\
\hline CD33 & 0.321 & 0.250 & 0.111 & 0.122 \\
\hline CELF1 & 0.353 & 0.223 & - & - \\
\hline CLU & 0.608 & 0.475 & 0.465 & 0.631 \\
\hline CR1 & 0.349 & 0.182 & 0.403 & 0.629 \\
\hline EPHA1 & 0.481 & 0.459 & 0.842 & 0.896 \\
\hline FERMT2 & 0.001 & 0.002 & - & - \\
\hline GRN & 0.310 & 0.453 & - & - \\
\hline HLA-DRB1 & 0.262 & 0.166 & - & - \\
\hline INPP5D & 0.140 & 0.200 & - & - \\
\hline MAPT & 0.673 & 0.668 & 0.596 & 0.677 \\
\hline MEF2C & 0.266 & 0.323 & - & - \\
\hline MS4A6A & 0.264 & 0.287 & 0.751 & 0.555 \\
\hline NME8 & 0.228 & 0.127 & - & - \\
\hline PICALM & 0.111 & 0.032 & - & - \\
\hline PLD3 & 0.169 & 0.146 & 0.348 & 0.305 \\
\hline PSEN1 & 0.755 & 0.418 & 0.154 & 0.089 \\
\hline PSEN2 & 0.725 & 0.444 & 0.080 & 0.173 \\
\hline PTK2B & 0.653 & 0.489 & 0.622 & 0.447 \\
\hline RIN3 & 0.419 & 0.341 & 0.935 & 0.958 \\
\hline SLC24A4 & 0.009 & 0.023 & 0.026 & 0.076 \\
\hline SORL1 & 0.642 & 0.438 & 0.263 & 0.172 \\
\hline TREM2 & 0.678 & 0.575 & 0.394 & 0.358 \\
\hline TREML2 & 0.381 & 0.300 & 0.208 & 0.143 \\
\hline ZCWPW1 & 0.560 & 0.478 & - & - \\
\hline
\end{tabular}

Bold indicates $p$-values $<0.05$.

Rare variation in NOS1AP was identified. NOS1AP lies under one of the HLOD linkage peaks, is expressed in the brain, ${ }^{29}$ and is known to interact with the LDL-receptor-related protein 1 (LRP1). LRP1 is an APOE receptor that helps bring APOE into neurons ${ }^{30,31}$ and APP. In addition, LRP has been associated with $\mathrm{AD}$ in the $\mathrm{ADSP}$ WES experiment $(p=0.00018){ }^{28}$
NOS1AP also interacts with nNOS, ${ }^{32}$ encoded by NOS1, which has been linked to $\mathrm{AD}^{33}$ as well as other neurologic diseases.

A missense variant (rs137854495) in ATP binding cassette subfamily A member 1 ( $A B C A 1)$ was found to segregate with disease in one family under a family-specific linkage peak on 
chromosome 9. The variant was rare, with a very high CADD score $(\mathrm{CADD}=34) \cdot A B C A 1$ is expressed in brain (though not exclusively; $A B C A 7$ is expressed in many tissues) and is involved in lipid removal pathways. ${ }^{29}$ Variants in $A B C A 1$ have been associated with HDL deficiency, familial hypercholesterolemia, and APOA deficiency. ${ }^{34-37}$ The rs137854495 variant, in particular, has been noted in a family with Tangier disease as part of a compound heterozygote. ${ }^{38}$ Dyslipidemias and lipid pathways have long been linked to $\mathrm{LOAD},{ }^{39}$ starting with the $A P O E$ gene, $^{3}$ and more recently $C L U, A B C A 7$, etc, ${ }^{4,22}$ although exact mechanisms remain unclear. Tangier disease, in particular, has also been proposed as having links to $\mathrm{AD}$, primarily through amyloid- $\beta$ pathways, although evidence supporting this is mixed. ${ }^{40-44}$ The ADSP WES project identified nominal association with 2 additional apolipoproteins (APOA2, $p=0.000636$; APOA5, $p=0.0413)$. ${ }^{28}$

Gene-based association tests implicated fermitin family member 2 (FERMT2) and surrounding genes STYX, PSMC6, and GNPNAT, all with similar levels of significance ( $p=$ $0.0010-0.0016)$. FERMT2 is involved in cell adhesion, is expressed in brain, and is near an SNP with strong association to $\mathrm{AD}{ }^{4}$ STYX is likely involved in phosphatase activity and has been associated with diabetes mellitus type $1 .{ }^{45}$ PSMC6 is likely involved in hydrolase activity; GNPNAT is involved in sugar metabolism. SLC24A4 has been associated with $\mathrm{AD}$ through a genome-wide meta-analysis, ${ }^{4}$ and brain methylation in SLC24A4 region has been associated with $\mathrm{AD}$ risk. ${ }^{46} \mathrm{Al}-$ though FERMT2 and SLC24A4 were initially identified using common variant approaches, the association observed at these 2 genes was not greatly affected by including the GWAS index SNPs as covariates in the model. If common variants were solely responsible for the association, then we would expect to fail to reject the null hypothesis at the rare variants. This implies the rare variation associated with disease in these families is distinct from the common variant index SNPs initially used to identify the genes.

There are limitations to this study. The sample size was modest relative to GWAS approaches. This of course limits power, particularly for the association-based approaches. However, the use of familial data and linkage and segregationbased approaches mitigates some of these power concerns. Increasing sample sizes and number of multiplex families is an ongoing effort for future studies. Additional limitations include the use of in silico predictions of function (e.g., CADD). While useful as a first pass, these predictions should be seen as a putative, ${ }^{47}$ and function will need to be validated by functional genetic approaches.

These results imply a role for rare variation in familial LOAD. The linkage analysis identified 41 high-priority variants, including variants in NOS1AP and $A B C A 1$, both with plausible roles in $\mathrm{AD}$ and $\mathrm{AD}$-related pathways. The analysis of LOAD candidate genes identified several genes with rare variation associated with $\mathrm{AD}$. The tests were still significant while controlling for the common index SNPs, implying a role for rare variation even at
GWAS-identified loci. Future directions include a thorough analysis on noncoding variation, particularly the role of enhancers and other regulatory elements in the etiology of $\mathrm{AD}$.

\section{Author contributions}

All authors contributed to the work presented in this article. Critical revision: Primary manuscript was prepared by G.W. Beecham, with significant contributions from B. Vardarajan, E. Blue, E. Wijsman, and M.A. Pericak-Vance. All authors participated in the revision and editing of the manuscript. Concept and design: There were significant contributions to concept and design from G.W. Beecham, B. Vardarajan, E. Blue, W. Bush, A. DeStefano, E.R. Martin, A. Naj, C. Reitz, C. van Duijn, A. Goate, S. Seshadri, L.A. Farrer, E. Boerwinkle, G. Schellenberg, J.L. Haines, E. Wijsman, R. Mayeux, and M.A. Pericak-Vance. Analysis and interpretation: Review of family data was performed by M. Pericak-Vance, R. Mayeux, E. Boerwinkle, S. Seshadri, and C. van Duijn. Primary statistical analyses were performed by G.W. Beecham, J. Jaworski, E.R. Martin, and K. Hamilton-Nelson, with additions from B. Vardarajan, W. Bush, and E. Blue. All authors participated in the interpretation and discussion of results. Acquisition of data: Sample data were contributed by C. van Duijn, A. DeStefano, L.A. Farrer, A. Goate, J.L. Haines, M.A. PericakVance, E. Boerwinkle, R. Mayeux, S. Seshadri, and G. Schellenberg. Statistical analyses: Statistical analyses were primarily conducted by G.W. Beecham; additional analyses conducted by J.C.B., A.C.N., E.R. Martin, S.H.C., A. DeStefano, and S. Seshadri (affiliations noted above, all academic). Study supervision and coordination: Primary study supervision and coordination was by R. Mayeux, M.A. Pericak-Vance, and E. Wijsman. Funding: Primary funding was by G. Schellenberg, R. Mayeux, E. Boerwinkle, M.A. Pericak-Vance, J.L. Haines, S. Seshadri, A. Goate, L.A. Farrer, and E. Wijsman. A detailed list of funding is noted in the acknowledgements.

\section{Acknowledgment}

The Alzheimer's Disease Sequencing Project (ADSP) comprises 2 Alzheimer disease $(\mathrm{AD})$ genetics consortia and 3 National Human Genome Research Institute-funded Large Scale Sequencing and Analysis Centers (LSAC). The $2 \mathrm{AD}$ genetics consortia are the Alzheimer's Disease Genetics Consortium (ADGC) funded by the National Institute on Aging (NIA; U01 AG032984), and the Cohorts for Heart and Aging Research in Genomic Epidemiology (CHARGE) funded by NIA (R01 AG033193), the National Heart, Lung, and Blood Institute (NHLBI), other NIH institutes and other foreign governmental and nongovernmental organizations. The Discovery Phase analysis of sequence data is supported through UF1AG047133 (to Drs. Farrer, Haines, Mayeux, Pericak-Vance, and Schellenberg); U01AG049505 to Dr. Seshadri; U01AG049506 to Dr. Boerwinkle; U01AG049507 to Dr. Wijsman; and U01AG049508 to Dr. Goate; and the Discovery Extension Phase analysis is supported through U01AG052411 to Dr. Goate, U01AG052410 to Dr. PericakVance, and U01 AG052409 to Drs. Seshadri and Fornage. Data generation and harmonization in the Follow-up Phases 
is supported by U54AG052427 to Drs. Schellenberg and Wang. The ADGC cohorts include: Adult Changes in Thought (ACT supported by NIA grant U01AG006781 to Drs. Larson and Crane), the Alzheimer's Disease Centers (ADC), the Chicago Health and Aging Project (CHAP), the Memory and Aging Project (MAP), Mayo Clinic (MAYO), Mayo Parkinson's Disease controls, University of Miami, the Multi-Institutional Research in Alzheimer's Genetic Epidemiology Study (MIRAGE), the National Cell Repository for Alzheimer's Disease (NCRAD), the National Institute on Aging Late Onset Alzheimer's Disease Family Study (NIA-LOAD), the Religious Orders Study (ROS), the Texas Alzheimer's Research and Care Consortium (TARC), Vanderbilt University/Case Western Reserve University (VAN/CWRU), the Washington Heights-Inwood Columbia Aging Project (WHICAP supported by NIA grant RF1AG054023 to Dr. Mayeux) and the Washington University Sequencing Project (WUSP), the Columbia University Hispanic-Estudio Familiar de Influencia Genetica de Alzheimer (EFIGA supported by NIA grant RF1AG015473 to Dr. Mayeux), the University of Toronto (UT), and Genetic Differences (GD). Analysis of ADGC cohorts was supported by NIA grants R01AG048927 and RF1AG057519 to Dr. Farrer. Efforts of ADGC investigators were also supported by grants from the NIA (R03AG054936) and National Library of Medicine (R01LM012535). The CHARGE cohorts are supported in part by NHLBI infrastructure grant HL105756 (Psaty) and RC2HL102419 (Boerwinkle), and the neurology working group is supported by the NIA R01 grant AG033193. The CHARGE cohorts participating in the ADSP include the following: Austrian Stroke Prevention Study (ASPS), ASPS-Family study, and the Prospective Dementia Registry-Austria (ASPS/PRODEM-Aus), the Atherosclerosis Risk in Communities (ARIC) Study, the Cardiovascular Health Study (CHS), the Erasmus Rucphen Family Study (ERF), the Framingham Heart Study (FHS), and the Rotterdam Study (RS). ASPS is funded by the Austrian Science Fond (FWF) grant number P20545-P05 and P13180 and the Medical University of Graz. The ASPS-Fam is funded by the Austrian Science Fund (FWF) project I904, the EU Joint ProgrammeNeurodegenerative Disease Research (JPND) in frame of the BRIDGET project (Austria, Ministry of Science) and the Medical University of Graz and the Steiermärkische Krankenanstalten Gesellschaft. PRODEM-Austria is supported by the Austrian Research Promotion agency (FFG) (Project No. 827462) and by the Austrian National Bank (Anniversary Fund, project 15435). ARIC research is carried out as a collaborative study supported by NHLBI contracts (HHSN268201100005C, HHSN268201100006C, HHSN268201100007C, HHSN268201100008C, HHSN268201100009C, HHSN268201100010C, HHSN268201100011C, and HHSN268201100012C). Neurocognitive data in ARIC is collected by U01 2U01HL096812, 2U01HL096814, 2U01HL096899, 2U01HL096902, 2U01HL096917 from the NIH (NHLBI, NINDS, NIA, and NIDCD) and with previous brain MRI examinations funded by R01-HL70825 from the NHLBI. CHS research was supported by contracts HHSN268201200036C, HHSN268200800007C, N01HC55222, N01HC85079, N01HC85080, N01HC85081, N01HC85082, N01HC85083, N01HC85086, and grants U01HL080295 and U01HL130114 from the NHLBI with additional contribution from the NINDS. Additional support was provided by R01AG023629, R01AG15928, and R01AG20098 from the NIA. FHS research is supported by NHLBI contracts N01-HC-25195 and HHSN268201500001I. This study was also supported by additional grants from the NIA (R01s AG054076, AG049607, and AG033040) and NINDS (R01 NS017950). The ERF study as a part of EUROSPAN (European Special Populations Research Network) was supported by European Commission FP6 STRP grant number 018947 (LSHG-CT-2006-01947) and also received funding from the European Community's Seventh Framework Programme (FP7/2007-2013)/grant agreement HEALTH-F4-2007-201413 by the European Commission under the programme "Quality of Life and Management of the Living Resources" of 5th Framework Programme (no. QLG2-CT-2002-01254). High-throughput analysis of the ERF data was supported by a joint grant from the Netherlands Organization for Scientific Research and the Russian Foundation for Basic Research (NWO-RFBR 047.017.043). The Rotterdam Study is funded by Erasmus Medical Center and Erasmus University, Rotterdam, the Netherlands Organization for Health Research and Development (ZonMw), the Research Institute for Diseases in the Elderly (RIDE), the Ministry of Education, Culture and Science, the Ministry for Health, Welfare and Sports, the European Commission (DG XII), and the municipality of Rotterdam. Genetic data sets are also supported by the Netherlands Organization of Scientific Research NWO Investments (175.010.2005.011, 911-03-012), the Genetic Laboratory of the Department of Internal Medicine, Erasmus MC, the Research Institute for Diseases in the Elderly (014-93-015; RIDE2), and the Netherlands Genomics Initiative (NGI)/ Netherlands Organization for Scientific Research (NWO), Netherlands Consortium for Healthy Aging (NCHA), project 050-060-810. All studies are grateful to their participants, faculty, and staff. The content of these manuscripts is solely the responsibility of the authors and does not necessarily represent the official views of the NIH or the U.S. Department of Health and Human Services. The ADES-FR study was funded by grants from the Clinical Research Hospital Program from the French Ministry of Health (GMAJ, PHRC, 2008/067), the CNR-MAJ, the JPND PERADES, the GENMED labex (LABEX GENMED ANR-10-LABX-0013), and the FP7 AgedBrainSysBio. Whole exome sequencing in the 3C-Dijon study was funded by the Fondation Leducq. This work was supported by the France Génomique National infrastructure, funded as part of the Investissements d'Avenir program managed by the Agence Nationale pour la Recherche (ANR10-INBS-09), the Centre National de Recherche en Génomique Humaine, the National Foundation forAlzheimer's disease and related disorders, the Institut Pasteur de Lille, Inserm, the Lille Métropole Communauté Urbaine council, and the French government's LABEX (laboratory of excellence 
program investment for the future) DISTALZ grant (Development of Innovative Strategies for a Transdisciplinary approach to Alzheimer's disease). The 3C Study supports are listed on the Study Website (three-city-study.com). The FinnAD Study at the University of Tampere was supported by The Academy of Finland: grants 286284 (T.L.), Competitive State Research Financing of the Expert Responsibility area of Tampere University Hospitals (grant X51001); Juho Vainio Foundation; Paavo Nurmi Foundation; Finnish Foundation for Cardiovascular Research; Finnish Cultural Foundation; Tampere Tuberculosis Foundation; Yrjö Jahnsson Foundation; Signe and Ane Gyllenberg Foundation; and Diabetes Research Foundation of Finnish Diabetes Association. The three LSACs are the Human Genome Sequencing Center at the Baylor College of Medicine (U54 HG003273), the Broad Institute Genome Center (U54HG003067), and the Washington University Genome Institute (U54HG003079).

\section{Study funding}

Supported by the NIH, primarily the National Institute on Aging (NIA), the National Heart, Lung, and Blood Institute, and the National Human Genome Research Institute. Primary support includes the Alzheimer's Disease Genetics Consortium funded by NIA (U01 AG032984), and the Cohorts for Heart and Aging Research in Genomic Epidemiology (CHARGE) funded by NIA (R01 AG033193), the Human Genome Sequencing Center at the Baylor College of Medicine (U54 HG003273), the Broad Institute Genome Center (U54HG003067), and the Washington University Genome Institute (U54HG003079). Additional funding of contributing sites is noted below in the acknowledgements.

\section{Disclosure}

G. Beecham has received research support from the NIH and the Department of Defense. B. Vardarajan reports no disclosures. E. Blue has received research support from the NIH and the Cystic Fibrosis Foundation and has been a grant reviewer for the NIH. W. Bush has served on the editorial board for BMC Biodata Mining and PLoS One and has received research support from the USDA, the Foundation for Food and Agriculture, NIDDK, and the National Institute on Aging (NIA). J. Jaworski, S. Barral, and A. DeStefano report no disclosures. K. Hamilton-Nelson has received research support from the NIH. B. Kunkle reports no disclosures. E. Martin serves on the editorial board of Frontiers in Statistical Genetics and Methodology; and holds a patent for Test for Linkage and Association in General Pedigrees: The Pedigree Disequilibrium Test. A. Naj, F. Rajabli, and C. Reitz report no disclosures. T. Thornton has received research support from the NIH. C. van Duijn reports no disclosures. A. Goate has served on the scientific advisory boards of Denali Therapeutics, Pfizer, and DZNE; has received travel funding/speaker honoraria from the Rainwater Foundation, the Indiana University ADRC advisory board, and Wellcome Trust; serves on the editorial board of eLife; holds patents for PSEN mutations in $\mathrm{AD}$, Tau mutations in FTD, and TDP43 mutations in
ALS $\backslash$ FTD; has been a consultant for Cognition Therapeutics, AbbVie, and Biogen; has received research support from $\mathrm{F}$ Prime, NIA, Rainwater Charitable Foundation, and JPB Foundation; and receives royalty payments from Taconic Industries for tau mutation patent, and from Athena Diagnostics for TDP43 mutation testing. S. Seshadri serves on the editorial boards of the Journal of Alzheimer's Disease, Stroke, and Neurology and has received research support from NIA and NINDS. L. Farrer serves on the editorial boards of the American Journal of Alzheimer's Disease \& Other Dementias, Clinical Genetics, and the Journal of Clinical Medicine; holds a patent (pending) for Use of PLXNA4 as a drug target and biomarker for Alzheimer disease; has been a consultant for Novartis Pharmaceuticals, Gerson Lerman, and Guidepoint Global; has received research support from the NIH, the Fidelity Foundation, and the Thome Memorial Foundation; and was a consultant for legal proceedings involving Finnegan \& Associates, LLP. E. Boerwinkle has received travel funding and speaker honoraria from the Harvard School of Public Health and the Metabolomics Forum in Cambridge, United Kingdom; serves on the editorial board of Annals of Epidemiology; is a scientific officer at Codified Genomics, LLC; and has received research support from the NIH. G. Schellenberg has served on scientific advisory boards for the Alzheimer's Association, the Society of Progressive Supranuclear Palsy, the United Kingdom Parkinson Disease Center, University College London, the Alzheimer's Disease Sequence Project (co-chair), Structural Variant Work Group, the Alzheimer's Disease Sequence Project, Mayo Clinic Rochester Udall Center, University of Miami Udall Center, Discovery Assessment Panel, and the Oxford Parkinson's Disease Centre; has received travel funding/speaker honoraria from $\mathrm{Alz}$ heimer's Disease Center, CurePSP, the University of California San Diego, Keystone Symposia, Southern California Alzheimer's Disease Research Conference, University of California Institute for Memory Impairment and Neurological Disorders, NIH, Novartis, McKnight Brain Institute, University of Florida, Keep Memory Alive Event Center, Cleveland Clinic, Accelerated Medicines Program, PSP/Lewy Body Disease Think-Tank, Alzheimer's Disease Center, American Association of Neuropathologists, Fusion Conferences, Center for Public Health Genomics, Columbia University, PSP Genetics Consortium, Tetra Institute, Rockefeller University, Blechman Foundation, Niigata University, Xuan Wu Hospital (Capital Medical University), Genetics of Dementia Summit (United Kingdom), Icahn School of Medicine Mount Sinai, and Biogen; has served on the editorial boards of the Journal of Neural Transmission, American Journal of Alzheimer's Disease and Other Dementias, Alzheimer's Research, Neurodegenerative Diseases, Current Alzheimer Research, and Pathology and Laboratory Medicine International; is employed by the University of Pennsylvania; has been a consultant for Biogen; and has received research support from the NIH, CurePSP, and CBD Solutions. J. Haines has served on the editorial boards of Neurogenetics, Current Protocols in Human Genetics, and Human Molecular Genetics; receives publishing royalties from John Wiley \& 
Sons; and has received research support from the NIH. E. Wijsman has served on the editorial boards of $B M C$ Proceedings and Faculty of 1000 and has received research support from the NIH and the Metropolitan Life Foundation.
R. Mayeux has received research support from the NIH. R. Pericak-Vance reports no disclosures. Full disclosure form information provided by the authors is available with the full text of this article at Neurology.org/NG.

APPENDIX 1 Co-investigators

\begin{tabular}{|c|c|c|}
\hline Affiliation & Full Name & Contributions \\
\hline \multirow[t]{23}{*}{ Baylor College of Medicine } & Adam English & $\begin{array}{l}\text { Baylor College of Medicine site contributed expertise to the study design, sequencing of samples, } \\
\text { bioinformatics analyses, quality control, data management, structural variation working group, as } \\
\text { well as input into both case-control and family study working groups }\end{array}$ \\
\hline & Divya Kalra & \\
\hline & Donna Muzny & \\
\hline & Evette Skinner & \\
\hline & $\begin{array}{l}\text { Harsha } \\
\text { Doddapeneni }\end{array}$ & \\
\hline & Huyen Dinh & \\
\hline & Jianhong $\mathrm{Hu}$ & \\
\hline & Jireh Santibanez & \\
\hline & Joy Jayaseelan & \\
\hline & Kim Worley & \\
\hline & Michelle Bellair & \\
\hline & Richard A. Gibbs & \\
\hline & Sandra Lee & \\
\hline & $\begin{array}{l}\text { Shannon Dugan- } \\
\text { Perez }\end{array}$ & \\
\hline & Simon White & \\
\hline & $\begin{array}{l}\text { Viktoriya } \\
\text { Korchina }\end{array}$ & \\
\hline & Waleed Nasser & \\
\hline & William Salerno & \\
\hline & Xiuping Liu & \\
\hline & Yi Han & \\
\hline & Yiming Zhu & \\
\hline & Yue Liu & \\
\hline & Ziad Khan & \\
\hline \multirow[t]{7}{*}{ Boston University } & $\begin{array}{l}\text { Adrienne } \\
\text { Cupples }\end{array}$ & $\begin{array}{l}\text { The Boston University site contributed expertise to the study design, bioinformatics analyses, } \\
\text { quality control, data management, structural variation working group, case-control working group, } \\
\text { family study working group, as well as significant sample contributions }\end{array}$ \\
\hline & Alexa Beiser & \\
\hline & Anita DeStefano* & \\
\hline & Ching Ti Liu & \\
\hline & Chloe Sarnowski & \\
\hline & Claudia Satizabal & \\
\hline & Dan Lancour & \\
\hline
\end{tabular}


APPENDIX 1 Co-investigators (continued)

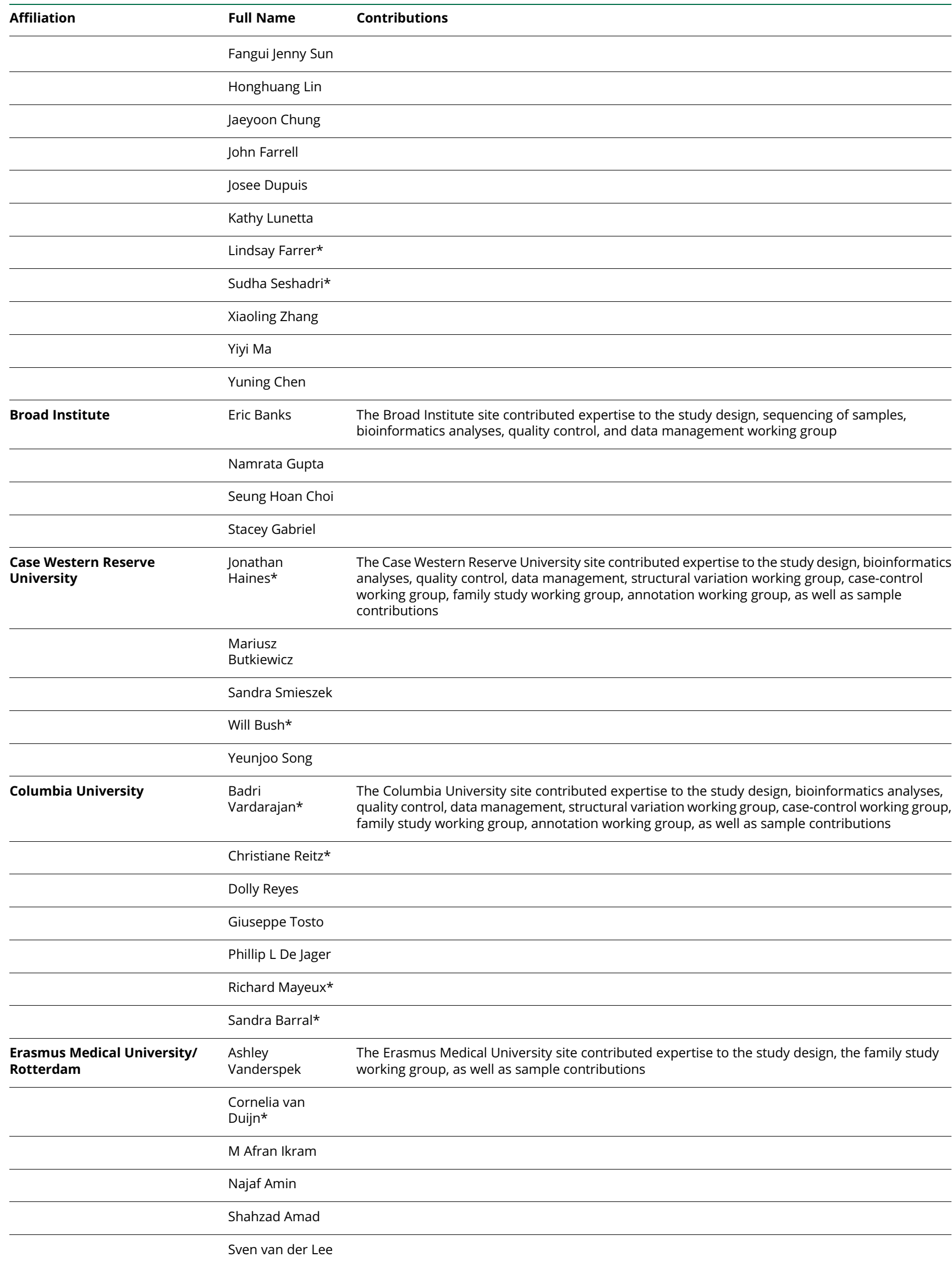


APPENDIX 1 Co-investigators (continued)

\begin{tabular}{|c|c|c|}
\hline Affiliation & Full Name & Contributions \\
\hline \multirow[t]{2}{*}{ Indiana University } & Kelley Faber & $\begin{array}{l}\text { The Indiana University site contributed expertise to the study design, data and sample collection } \\
\text { and management, participated in the family and case-control working groups }\end{array}$ \\
\hline & Tatiana Foroud & \\
\hline \multirow{2}{*}{$\begin{array}{l}\text { Medical University Graz, } \\
\text { Austria }\end{array}$} & Helena Schmidt & Medical University Grace contributed data and samples to the study \\
\hline & $\begin{array}{l}\text { Reinhold } \\
\text { Schmidt }\end{array}$ & \\
\hline \multirow[t]{4}{*}{$\begin{array}{l}\text { Mount Sinai School of } \\
\text { Medicine }\end{array}$} & Alan Renton & $\begin{array}{l}\text { The Mount Sinai site contributed samples as well as expertise to the design of the study, the family } \\
\text { and case-control working groups, and the protective variant working group }\end{array}$ \\
\hline & Alison Goate* & \\
\hline & $\begin{array}{l}\text { Edoardo } \\
\text { Marcora }\end{array}$ & \\
\hline & Manav Kapoor & \\
\hline \multirow{2}{*}{$\begin{array}{l}\text { National Center for } \\
\text { Biotechnology Information }\end{array}$} & Adam Stine & National Center for Biotechnology Information site contributed expertise to data management \\
\hline & Michael Feolo & \\
\hline National Institutes of Aging & Lenore J. Launer & National Institute on Aging site contributed expertise to data and study management \\
\hline Rush University & David A Bennett & Rush University site contributed samples and data to the study \\
\hline Stanford University & Li Charlie Xia & The Stanford University site contributed expertise to the structural variation working group \\
\hline \multirow[t]{8}{*}{ University of Miami } & Brian Kunkle* & $\begin{array}{l}\text { The University of Miami site contributed expertise to the study design, bioinformatics analyses, } \\
\text { quality control, data management, structural variation working group, case-control working group, } \\
\text { family study working group, as well as significant sample contributions }\end{array}$ \\
\hline & Eden Martin* & \\
\hline & Farid Rajabli* & \\
\hline & Gary Beecham* & \\
\hline & James Jaworski* & \\
\hline & $\begin{array}{l}\text { Kara Hamilton- } \\
\text { Nelson* }\end{array}$ & \\
\hline & $\begin{array}{l}\text { Margaret } \\
\text { Pericak-Vance* }\end{array}$ & \\
\hline & Michael Schmidt & \\
\hline University of Mississippi & $\begin{array}{l}\text { Thomas H. } \\
\text { Mosley }\end{array}$ & The University of Mississippi site contributed samples and data to the study \\
\hline \multirow[t]{10}{*}{ University of Pennsylvania } & Amanda Kuzma & $\begin{array}{l}\text { The University of Pennsylvania site contributed expertise to the study design, bioinformatics } \\
\text { analyses, quality control, data management, structural variation working group, case-control } \\
\text { working group, and family study working groups }\end{array}$ \\
\hline & Han-Jen Lin & \\
\hline & Liming Qu & \\
\hline & Li-San Wang & \\
\hline & Micah Childress & \\
\hline & Otto Valladares & \\
\hline & $\begin{array}{l}\text { Prabhakaran } \\
\text { Gangadharan }\end{array}$ & \\
\hline & Rebecca Cweibel & \\
\hline & Yi Zhao & \\
\hline & Yi-Fan Chou & \\
\hline
\end{tabular}


APPENDIX 1 Co-investigators (continued)

\begin{tabular}{|c|c|c|}
\hline \multirow[t]{10}{*}{ Affiliation } & Full Name & Contributions \\
\hline & Adam Naj* & \\
\hline & Elisabeth & \\
\hline & Mlynarski & \\
\hline & $\begin{array}{l}\text { Gerard } \\
\text { Schellenberg* }\end{array}$ & \\
\hline & John Malamon & \\
\hline & Laura Cantwell & \\
\hline & Nancy Zhang & \\
\hline & Weixin Wang & \\
\hline & Yuk Yee Leung & \\
\hline \multirow[t]{6}{*}{ University of Texas Houston } & Eric Boerwinkle* & $\begin{array}{l}\text { The University of Texas Houston site contributed expertise to the study design, sequencing of } \\
\text { samples, bioinformatics analyses, quality control, data management, structural variation working } \\
\text { group, as well as both case-control and family study working groups }\end{array}$ \\
\hline & Jan Bressler & \\
\hline & Jennifer E. Below & \\
\hline & Myriam Fornage & \\
\hline & Xiaoming Liu & \\
\hline & Xueqiu Jian & \\
\hline \multirow[t]{19}{*}{ University of Washington } & $\begin{array}{l}\text { Alejandro Q Nato } \\
\text { Jr. }\end{array}$ & $\begin{array}{l}\text { The University of Washington site contributed expertise to the bioinformatics analyses, quality } \\
\text { control, data management, structural variation working group, case-control working group, and } \\
\text { family study working group }\end{array}$ \\
\hline & $\begin{array}{l}\text { Andrea R } \\
\text { Horimoto }\end{array}$ & \\
\hline & Bowen Wang & \\
\hline & Bruce Psaty & \\
\hline & Daniela Witten & \\
\hline & Debby Tsuang & \\
\hline & Elizabeth Blue* & \\
\hline & Ellen Wijsman* & \\
\hline & Harkirat Sohi & \\
\hline & Hiep Nguyen & \\
\hline & Joshua C. Bis & \\
\hline & Kenneth Rice & \\
\hline & Lisa Brown & \\
\hline & $\begin{array}{l}\text { Michael } \\
\text { Dorschner }\end{array}$ & \\
\hline & Mohamad Saad & \\
\hline & Pat Navas & \\
\hline & Rafael Nafikov & \\
\hline & $\begin{array}{l}\text { Timothy } \\
\text { Thornton* }\end{array}$ & \\
\hline & Tyler Day & \\
\hline
\end{tabular}


APPENDIX 1 Co-investigators (continued)

\begin{tabular}{lll}
\hline Affiliation & Full Name & Contributions \\
\hline $\begin{array}{l}\text { Washington University St. } \\
\text { Louis }\end{array}$ & Carlos Cruchaga & $\begin{array}{l}\text { The Washington University St. Louis site contributed expertise to the study design, sequencing of } \\
\text { samples, bioinformatics analyses, quality control, data management, structural variation working } \\
\text { group, as well as both case-control and family study working groups }\end{array}$ \\
\hline
\end{tabular}

Daniel C. Koboldt

David E. Larson

Elizabeth

Appelbaum

Jason Waligorski

Lucinda

Antonacci-Fulton

Richard K. Wilson

Robert S. Fulton

Asterisks (*) indicate coinvestigators whose contributions were sufficient for authorship.

Received February 6, 2018. Accepted in final form October 3, 2018.

\section{References}

1. Lane CA, Hardy J, Schott JM. Alzheimer's disease. Eur J Neurol 2018;25:59-70.

2. Gatz M, Pedersen NL, Berg S, et al. Heritability for Alzheimer's disease: the study of dementia in Swedish twins. J Gerontol A Biol Sci Med Sci 1997;52: M117-M125.

3. Corder EH, Saunders AM, Strittmatter WJ, et al. Gene dose of apolipoprotein E type 4 allele and the risk of Alzheimer's disease in late onset families. Science 1993;261: 921-923.

4. Lambert JC, Ibrahim-Verbaas CA, Harold D, et al. Meta-analysis of 74,046 individuals identifies 11 new susceptibility loci for Alzheimer's disease. Nat Genet 2013;45: $1452-1458$.

5. Naj AC, Jun G, Beecham GW, et al. Common variants at MS4A4/MS4A6E, CD2AP, CD33 and EPHA1 are associated with late-onset Alzheimer's disease. Nat Genet 2011;43:436-441.

6. Guerreiro R, Wojtas A, Bras J, et al. TREM2 variants in Alzheimer's disease. N Engl J Med 2013;368:117-127.

7. Reitz C, Mayeux R. Alzheimer's Disease Genetics C. TREM2 and neurodegenerative disease. N Engl J Med 2013;369:1564-1565.

8. Le Guennec K, Nicolas G, Quenez O, et al. ABCA7 rare variants and Alzheimer disease risk. Neurology 2016;86:2134-2137.

9. Vardarajan BN, Zhang Y, Lee JH, et al. Coding mutations in SORL1 and Alzheimer disease. Ann Neurol 2015;77:215-227.

10. Beecham GW, Bis JC, Martin ER, et al. The Alzheimer's disease sequencing project: study design and sample selection. Neurol Genet 2017;3:e194.

11. Preston MD, Dudbridge F. Utilising family-based designs for detecting rare variant disease associations. Ann Hum Genet 2014;78:129-140.

12. Vardarajan BN, Barral S, Jaworski J, et al. Whole genome sequence analysis of caribbean hispanic families with late-onset Alzheimer's disease. Ann Clin Transl Neurol 2018;5:406-417.

13. McKhann G, Drachman D, Folstein M, Katzman R, Price D, Stadian EM. Clinical diagnosis of Alzheimer's disease: report of the NINCDS-ADRDA work group under the auspices of department of Health and human services task force on Alzheimer's disease. Neurology 1984;34:939-944.

14. Naj AC, Lin H, Vardarajan BN, et al. Quality control and integration of genotypes from two calling pipelines for whole genome sequence data in the Alzheimer's disease sequencing project. Genomics Epub 2018 May 29.

15. Li H, Durbin R. Fast and accurate short read alignment with Burrows-Wheeler transform. Bioinformatics 2009;25:1754-1760.

16. Challis D, Yu J, Evani US, et al. An integrative variant analysis suite for whole exome next-generation sequencing data. BMC Bioinformatics 2012;13:8.

17. Price AL, Patterson NJ, Plenge RM, Weinblatt ME, Shadick NA, Reich D. Principal components analysis corrects for stratification in genome-wide association studies. Nat Genet 2006;38:904-909.

18. Abecasis GR, Cherny SS, Cookson WO, Cardon LR. Merlin - rapid analysis of dense genetic maps using sparse gene flow trees. Nat Genet 2002;30:97-101.

19. Kunkle BW, Jaworski J, Barral S, et al. Genome-wide linkage analyses of non-Hispanic white families identify novel loci for familial late-onset Alzheimer's disease. Alzheimers Dement 2016;12:2-10.

20. Purcell S, Neale B, Todd-Brown K, et al. PLINK: a toolset for whole-genome association and population-based linkage analysis. Am J Hum Genet 2007;81:559-575.
21. Lander E, Kruglyak L. Genetic dissection of complex traits: guidelines for interpreting and reporting linkage results. Nat Genet 1995;11:241-247.

22. Kircher M, Witten DM, Jain P, O’Roak BJ, Cooper GM, Shendure J. A general framework for estimating the relative pathogenicity of human genetic variants. Nat Genet 2014:46:310-315.

23. Maurano MT, Haugen E, Sandstrom R, et al. Large-scale identification of sequence variants influencing human transcription factor occupancy. Nat Genet 2015;47:1393-1400.

24. The 1000 Genomes Project Consortium. A global reference for human genetic variation. Nature 2015;526:68-74.

25. Butkiewicz M, Blue E, Leung F, et al. Functional annotation of genomic variants in studies of Late-onset Alzheimer's disease. Bioinformatics 2018;34:2724-2731.

26. Yan $\mathrm{Q}$ Tiwari $\mathrm{HK}, \mathrm{Yi}$ N, et al. A sequence kernel association test for dichotomous traits in family samples under a generalized linear mixed model. Hum Hered 2015;79: 60-68.

27. Kholi MA, Cukier HN, Hamilton-Nelson KL, et al. Segregation of a rare TTC3 variant in an extended family with late-onset Alzheimer disease. Neurol Genet 2016;2:e41.

28. Bis JC, Jian X, Kunkle BW, et al. Whole exome sequencing study identifies novel rare and common Alzheimer's-Associated variants involved in immune response and transcriptional regulation. Mol Psychiatry Epub 2018 Aug 14.

29. Melé M, Ferreira PG, Reverter F, et al. Human genomics: the human transcriptome across tissues and individuals. Science 2015;348:660-665.

30. Beisiegel U, Weber W, Ihrke G, Herz J, Stanley KK. The LDL-receptor-related protein, LRP, is an apolipoprotein E-binding protein. Nature 1989;341: $162-164$.

31. Vázquez-Higuera JL, Mateo I, Sánchez-Juan P, et al. Genetic interaction between tau and the apolipoprotein E receptor LRP1 Increases Alzheimer's disease risk. Dement Geriatr Cogn Disord 2009;28:116-120.

32. Jaffrey SR, Snowman AM, Eliasson MJ, Cohen NA, Snyder SH. CAPON: a protein associated with neuronal nitri oxide synthase that regulates its interactions with PSD95. Neuron 1998;20:115-124.

33. Galimberti D, Scarpini E, Venturelli E, et al. Association of a NOS1 promoter repeat with Alzheimer's disease. Neurobiol Aging 2008;29:1359-1365.

34. Villarreal-Molina MT, Aguilar-Salinas CA, Rodríguez-Cruz M, et al. The ATP-binding cassette transporter A1 R230C variant affects HDL cholesterol levels and BMI in the Mexican population: association with obesity and obesity-related comorbidities. Diabetes 2007;56:1881-1887.

35. Rhyne J, Mantaring MM, Gardner DF, Miller M. Multiple splice defects in ABCA1 cause low HDL-C in a family with hypoalphalipoproteinemia and premature coronary disease. BMC Med Genet 2009;10:1.

36. Cenarro A, Artieda M, Castillo S, et al. A common variant in the ABCA1 gene is associated with a lower risk for premature coronary heart disease in familial hypercholesterolaemia. J Med Genet 2003;40:163-168.

37. Brooks-Wilson A, Marcil M, Clee SM, et al. Mutations in ABC1 in Tangier disease and familial high-density lipoprotein deficiency. Nat Genet 1999;22:336-345.

38. Bodzioch $\mathrm{M}$, Orsó $\mathrm{E}$, Klucken J, et al. The gene encoding ATP-binding cassette transporter 1 is mutated in Tangier disease. Nat Genet 1999;22:347-351.

39. Reitz C. Dyslipidemia and the risk of Alzheimer's disease. Curr Atheroscler Rep 2013; 15:307.

40. Kim WS, Hill AF, Fitzgerald ML, et al. Wild type and Tangier disease ABCA1 mutants modulate cellular amyloid- $\beta$ production independent of cholesterol efflux activity. J Alzheimers Dis 2011;27:441-452. 
41. Pervaiz MA, Gau G, Jaffe AS, Saenger AK, Baudhuin L, Ellison J. A non-classical presentation of tangier disease with three ABCA1 mutations. JIMD Rep 2012;4:109-111.

42. Fan J1, Donkin J, Wellington C. Greasing the wheels of Abeta clearance in Alzheimer's disease: the role of lipids and apolipoprotein E. Biofactors 2009;35:239-248.

43. Fitz NF, Cronican AA, Saleem M, et al. Abcal deficiency affects Alzheimer's diseaselike phenotype in human ApoE4 but not in ApoE3-targeted replacement mice. J Neurosci 2012;32:13125-13136.

44. Shahim P1, Bochem AE, Mattsson N, et al. Plasma amyloid- $\beta$ in patients with Tangier disease. J Alzheimers Dis 2013;35:307-312.
45. Palomer X1, Mauricio D, Rodríguez-Espinosa J, et al. Evaluation of two nonisotopic immunoassays for determination of glutamic acid decarboxylase and tyrosine phosphatase autoantibodies in serum. Clin Chem 2004;50:1378-1382.

46. Yu L, Chibnik LB, Srivastava GP, et al. Association of Brain DNA methylation in SORL1, ABCA7, HLA-DRB5, SLC24A4, and BIN1 with pathological diagnosis of Alzheimer disease. JAMA Neurol 2015;72:15-24.

47. Mather CA, Mooney SD, Salipante SJ. CADD score has limited clinical validity for the identification of pathogenic variants in noncoding regions in a hereditary cancer panel. Genet Med 2016;18:1269-1275. 


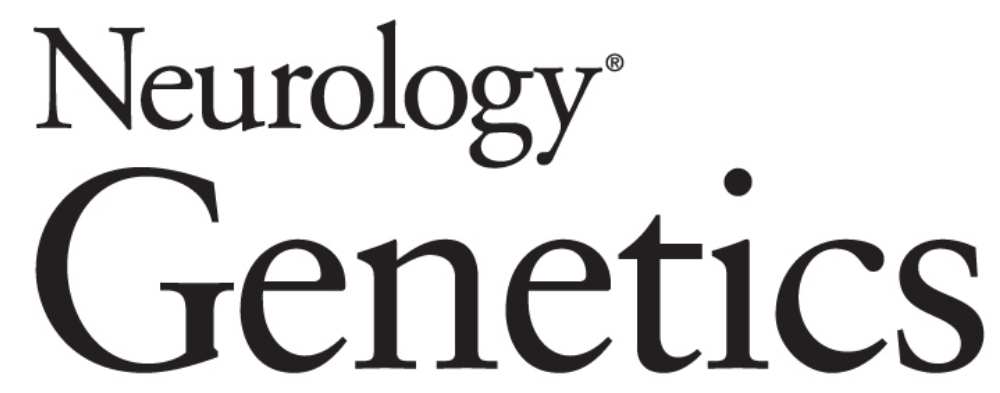

Rare genetic variation implicated in non-Hispanic white families with Alzheimer
disease

Gary W. Beecham, Badri Vardarajan, Elizabeth Blue, et al. Neurol Genet 2018;4;

DOI 10.1212/NXG.0000000000000286

This information is current as of November 26, 2018

Neurol Genet is an official journal of the American Academy of Neurology. Published since April 2015, it is an open-access, online-only, continuous publication journal. Copyright Copyright ( 2018 The Author(s). Published by Wolters Kluwer Health, Inc. on behalf of the American Academy of Neurology.. All rights reserved. Online ISSN: 2376-7839.

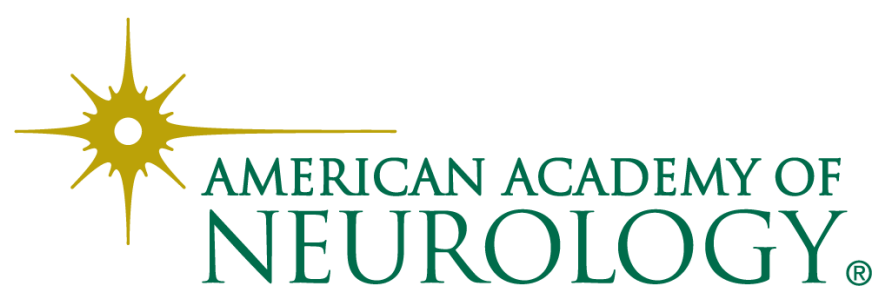




\section{Updated Information \& Services}

References

Citations

Subspecialty Collections

Permissions \& Licensing

Reprints including high resolution figures, can be found at: http://ng.neurology.org/content/4/6/e286.full.html

This article cites 45 articles, 8 of which you can access for free at: http://ng.neurology.org/content/4/6/e286.full.html\#\#ref-list-1

This article has been cited by 2 HighWire-hosted articles: http://ng.neurology.org/content/4/6/e286.full.html\#\#otherarticles

This article, along with others on similar topics, appears in the following collection(s):

Alzheimer's disease

http://ng.neurology.org//cgi/collection/alzheimers_disease Association studies in genetics

http://ng.neurology.org//cgi/collection/association_studies_in_genetics Genetic linkage

http://ng.neurology.org//cgi/collection/genetic_linkage

Information about reproducing this article in parts (figures,tables) or in its entirety can be found online at:

http://ng.neurology.org/misc/about.xhtml\#permissions

Information about ordering reprints can be found online:

http://ng.neurology.org/misc/addir.xhtml\#reprintsus

Neurol Genet is an official journal of the American Academy of Neurology. Published since April 2015, it is an open-access, online-only, continuous publication journal. Copyright Copyright $\odot 2018$ The Author(s). Published by Wolters Kluwer Health, Inc. on behalf of the American Academy of Neurology.. All rights reserved. Online ISSN: 2376-7839.

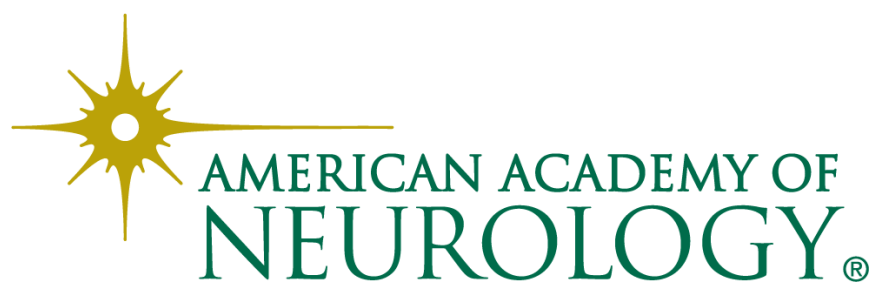

